April Meeting, Friday, April 1st, 1892.

The meeting was called to order in the Chapel of the University Building, at 8.30 P. M.; the President, Prof. G. C. Caldwell in the chair.

The minutes of the March meeting were read and accepted.

The following members were elected :

Howard V. Frost, Ph. D., Pol. Inst., Brooklyn, E. D.

Mr. C. McLaughlin, 8\%4 Broadway, N. Y.

Mr. David M. Lichty, Ann Arbor, Mich.

Prof. W. R. Orndorff, Cornell University, Ithaca, N. Y.

Mr. J. F. Rogers, $16 \tau$ Prospect st., Providence, R. I.

Julius 0. Schlötterbeck, B. S., Ann Arbor, Mich.

As Associates:

Mr. Ottomar Eberbach,
Wm. F. Edwards, B. S., $\}$ Ann Arbor, Mich.

The following names were rend for nomination to membership:

Mr. A. E. Menke, Fayetteville, Ark.

Dr. Leo Baekeland, 1964 ith ave., N. Y.

Dr. S. Burton, Waco, Texas.

Mr. John 'T. Enequist, Bushwick Chem. Works, Brooklyn.

Mr. Roland Molineaux, 108 Fulton st., N. Y.

From associate to regular membership:

Mr. Ottomar Eberbach,
Mr. Wm. F. Ed wards, Ann Arbor, Mich.

President Caldwell then read an address on :

"The more Important Events in the Progress in Agricultural Chemistry since 1870."

A paper on

"Denitration of Pyroxylin," by Durand Woodman, was read by the anthor.

The meeting was then adjourned.

DURAND WOODMAX, Recording Secretary. 


\section{The New York Sectiox.}

A meeting of the N. Y. members was held at the close of the regular meeting, and it was resolved that a committee of five be appointed by the Chair to consider the form of organization of the N. Y. Section and report at the May meeting.

The Chair appointed Prof. Wm. McMurtrie, Prof. A. H. Sabin, Prof. A. C. Hale, Prof. C. A. Doremns, Mr. J. F. Geisler. 